\title{
Genomic regions related to white/black tail feather color in Dwarf chickens detected using a genome-wide association study
}

\section{Changsheng Nie}

China Agricultural University

\section{Liang Qu}

Jiangsu Institute of Poultry Science, Chinese Academy of Agricultural Science

Zhihua Jiang

Washington State University

\section{Kehua Wang}

Jiangsu Institute of Poultry Science, Chinese Academy of Agricultural Science

Lujiang Qu ( $\nabla$ quluj@163.com )

China Agricultural University

\section{Zhonghua Ning}

China Agricultural University

\section{Research article}

Keywords: Dwarf chicken; tail feather color; GWAS

Posted Date: June 19th, 2019

DOI: https://doi.org/10.21203/rs.2.10336/v1

License: @ (1) This work is licensed under a Creative Commons Attribution 4.0 International License. Read Full License 


\section{Abstract}

Background: The genetic foundation of chicken tail feather color is not very well studied to date, though that of body feather color is extensively explored. In the present study, we used a synthetic chicken dwarf line (DW), which was originated from the hybrids between a black tail chicken breed, Rhode Island Red (RIR) and a white tail breed, Dwarf Layer (DL), to understand the genetic rules of the white/black tail color. The DW line still contain the individuals with black or white tails, even if the body feather are predominantly red, after more than ten generation of self-crossing and being selected for the body feather color. We firstly performed four crosses using the DW line chickens including black tail male to female, reciprocal crosses between the black and white, and white male to female to elucidate the inheritance pattern of the white/black tail. Furtherly, we performed a genome-wide association (GWA) analysis to determine the candidate genomic regions underlying the tail feather color by using black tail chickens from the RIR and DW chickens and white individuals from DW lines. Results: In the cross experiment, we found that (i) the white/black tail feather colors are independent of body feather color and (ii) the phenotype are autosomal simple trait and (iii) the white are dominant to the black in the DW lines. The GWA results showed that seven Single-nucleotide polymorphism (SNP) on chromosome 24 were significantly correlated with tail feather color. The significant region (3.97-4.26 Mb) perches nine known genes and five anonymous genes. The nine genes were: NECTIN1, THY1, ggamir-1466, USP2, C1QTNF5, RNF26, MCAM, CBL and CCDC153. Conclusions: The study has revealed the white/black tail feather trait is autosome-linked in Dwarf chickens. In the genome significant $\sim 0.29 \mathrm{Mb}$ region, fourteen genes were found and some of them could play critical roles in the formation of white/black tail feather color, especially gene MCAM. Taken together, our research is the first study on genetics of tail feather color and could help the more understanding of feather pigmentation in chicken.

\section{Background}

As a part of feather, tail feather color could be exhibited differently from body feather color in birds. Compared to body feather color, it is not very well documented about the genetic of tail feather color in chickens. The tail feather color is a naturally and sexually selected trait in chickens and wild birds, such as rock sparrows [ 1], barn swallows [ 2], and peacocks [ 3], and combined with artificial selection in poultry, especially in chickens. Black and white are predominant tail feather colors in chickens, and in some breeds, chickens also could present the red, blue, yellow, purple, or multi-colored tail feathers.

Feather color is genetically complex trait and the genetic foundation is extensively explored in birds [ 4, 5], specifically in chickens. The plumage color in chickens are most diversified and studied. The dominant white, dun, and smoky color are associated with the PMEL 17 polymorphism [ 6]. The mutation in MLPH causes the dilution of both black eumelanin and red/brown pheomelanin pigments [ 7]. Furthermore, more than one gene, example, $\operatorname{TYR}[8,9]$ and $S L C 45 A 2$ [ 10], can produce white feather color. The extended black plumage has been related to $M C 1 R$ [11-14]. Sex-linked barring feather was controlled by the $C D K N 2 A / B$ [ 15].

The inheritance of chicken tail color is rarely studied as an isolate trait, though almost all kinds of chick plumage color are explored. Generally, geneticist would have regarded the tail color as a part of plumage color, since the tail color are strongly interacted with body feather color in some chicken breeds. The dominant white chickens are always with white tails (Figure $1 \mathrm{~A}$ ) and the barred plumage individuals also have the barred tails (Figure 1B). However, the segregation of the tail feather color and body feather color are widely presented in some breeds (Figure $1 \mathrm{C}-\mathrm{F}$ ). And also, the daughters of male Rhode Island Red (RIR) (with sex-linked recessive red plumage and black tail, Figure 1G) and female Rhode Island White (RIW) (with sex-linked dominant white plumage, Figure 1H) present red body feather and white tail color, indicating that body feather color and tail color are controlled by different genes in the chickens. We also observed that a dwarf line (DW) hybrids (Figure 2) from more than ten generation self-crossing between RIR and a white tailed dwarf layer (DL) contain both white and red tail individuals even if the hybrids were selected for red body feather color. So we used the population to understand the genetic basement of white/black tail phenotypes in the chicken in our study.

\section{Materials And Methods}

\section{Animals}

The birds used in this study were derived from two chicken populations (Beinongda commercial breeding farm and Jiangsu Institute of Poultry Science experiment farm), RIR and DL chickens. RIR, a dual-purpose commercial breed, has red body feather and black tail feather and the red feather are determined by a $Z$ chromosome linked recessive allele. The DL chicken is a layer line with white feather which was decided by a Z linked dominant allele. The DW chickens with white and black tail feathers were generated by more than ten 
generation self-crossing of RIR and DL. Since only the red body feather color was selected in each generation regardless the tail color, DL population present both black and white tail colors, with most of them being red body feather color (Figure 2).

\section{Inheritance pattern of tail feather colors}

We performed four crosses using the black tailed DW and white tailed DW including black $\times$ black (cross 1 ), black males $\times$ white females (cross 2), white males $\times$ black females (cross 3 ), and white $\times$ white (cross 4 ), in order to explain the inheritance pattern of the tail colors. We did two replicates of the four crosses (cross 5-8) to confirm our results. We identified the tail feather color at the age of 7 weeks of chicken when the tail feather came out.

\section{Mapping the genomic region underlying white/black tail feather colors by a GWAS}

A total of 176 adult female chickens were selected, including 96 black-tailed RIRs and 80 DWs (38 black-tailed and 42 white-tailed) to perform the GWAS (Figure 2). Blood samples were collected using an injection via the wing vein into centrifuge tubes containing DNA anti-coagulating agent from these two populations.

The genomic DNA was extracted by the standard phenol/chloroform method [ 16] and genotyped using a $600 \mathrm{~K}$ Affymetrix Axiom Chicken Genotyping Array (Affymetrix, Inc. Santa Clara, CA, USA) [ 17]. Affymetrix Power Tools v1.16.0 (APT) software was then used for quality control and genotype calling. Specifically, only samples with dish quality control (DQC) $>0.82$ and call rate $>97 \%$ were used in the subsequent analysis.

The SNPs with a minor allele frequency $<1 \%$ or a $\mathrm{P}$ value of deviation from HardyWeinberg equilibrium $\left(\mathrm{PHWE}<1 \times 10^{-6}\right)$ were removed. Ultimately, 175 individuals and 479,579 SNPs were retained for the association analysis mentioned below. The classical multidimensional scaling (MDS) analysis was used to detect the population structure using PLINK v1.09 software [ 18].

\section{Statistical analysis}

To test the association of each SNP with the tail feather color, we used the mixed model [ 19] association analysis, including fixed effects (overall mean and covariates) and random effects (SNP effect, individual effect, and residual errors), according to the manual of GEMMA (v0.94.1) [20]. In the present study, 175 genotyped birds were collected from two different populations, and therefore, the first two principal components (accounting for $23.89 \%$ and $2.31 \%$ of the total variability) were used as a covariate to account for population structure in the analysis.

All the selected SNPs were subjected to linkage disequilibrium analysis, using the -indep-pairwise 2550.2 and -blocks-max-kb 500 commend in PLINK, to generate a pruned subset of 48,848 SNPs and 77,137 haploblocks with linkage equilibrium. Bonferroni adjustment is a widely used method for multiple hypothesis testing. Given the correlation between the SNPs in linkage disequilibrium, the traditional Bonferroni adjustment appears to be overly conservative, with the key assumption that all the tests are independent [21]. Herein, the sum of independent blocks plus singleton markers was used to define the number of independent statistical tests [22, 23]. With this approach, 125,985 independent tests were suggested to determine the $P$ value threshold. Therefore, the genome-wide significant and suggestive P-values were $3.97 \times 10^{-7}(0.05 / 125,985)$ and $7.94 \times 10^{-6}(1 / 125,985)$, respectively.

In addition, the annotated genes were identified using the NCBI and Ensembl annotation of the Gallus gallus 5.0 genome version. Manhattan plot of genome-wide P-values of the association analysis was created using R (https://www.r-project.org/).

\section{Results}

\section{White tail feather color in Dwarf chicken is an autosome-linked dominant character}


We firstly made four crosses between white tail and black tail chicken and the body feather color of the chickens are all red. Since there are a few outliers identified in the 4 crosses, we generated the other four crosses to confirm our results. Almost all of the offspring present red body feather with few exceptions showing gray or white body feather color (Figure 3). Due to body feather color could affect the tail color, we only used the offspring with red body feather color to understand the inheritance pattern of white/black tail color. Table 1 presents distribution of white or black tail progenies in the 8 crosses.

We found that the white/black tail feather color is a Mendelian inheritance trait and the white is dominant to the black (table 1). And the same results were shown by both replicates. Since, the segregation of the red body feather and tail color, we can conclude that the white/red tail color was controlled by different genes with the red body feather color and also, there is no epistatic effect between them.

\section{Candidate genes on chromosome 24 detected by the GWAS}

After quality control, 175 female chickens were analyzed, of which 134 (76\%) presented black tail feather color as the controls and 41 (24\%) presented white tail feather color as the cases. Based on Manhattan plot for the white/black tail feather color, we observed seven significantly associated SNPs spanning from 3.97 to $4.26 \mathrm{Mb}(\sim 0.29 \mathrm{Mb})$ on chromosome $24\left(\mathrm{P}<3.97 \times 10^{-7}\right)$ in the sexually mature hens (Figure 4 and Table 2). Moreover, fourteen candidate genes were found related to the tail feather color phenotype, including nine annotated genes and five anonymous genes, namely, NECTIN1, THY1, gga-mir-1466, USP2, C1QTNF5, RNF26, MCAM, CBL, CCDC153, ENSGALG00000046117, ENSGALG00000006746, ENSGALG00000037367, ENSGALG00000032979, and ENSGALG00000039907.

Additionally, 36 autosomal SNPs were suggestively related $\left(7.94 \times 10^{-6}\right)$ to the white/black tail feather in chicken (Figure 4).

\section{Discussion}

The tail feather color (white/black) in DW chicken is a qualitative trait. We assumed that it was controlled by a single gene. The results of our crossing experiments supported our assumption, and revealed that the white tail feather in DW is an autosome-linked dominant trait. However, the crosses produced some white body plumage and gray tail feathers in some offspring (Table 1), which has two possible explanations. First, the body and tail feather colors were not controlled by the same gene in DW chickens. Second, an intermediate type of feather existed in the population at an early development period, and most of the heterozygous individuals were classified as having gray tail feathers, but a few of them might have been counted as black- or white-tailed by mistake.

We also aimed to locate positional candidate genes associated with tail feather color using a 600K SNP panel for genotyping DW and RIR chickens. We identified 14 candidate genes were detected in the most significant region on chromosome 24, which corresponded to nine known and five anonymous genes.

The candidate gene, melanoma cell adhesion molecule (MCAM) encoding an endothelial adhesion receptor or an independent receptor of fibroblast growth factor 4, was identified to play an essential role in lymphocyte endothelium interaction and morphogenesis process [ $25,26]$. It has been demonstrated that melanocytes are derived from melanoblasts that originate from neural crest cells in the early embryos [ 35], and fibroblasts can influence melanogenesis [ 36, 37]. Furthermore, Mangahas et al. [ 38] has reported that human MCAM is involved in primary melanocyte development via endothelin upregulation. Endothelin 3 locus has been reported to cause hyperpigmentation in chicken [39]. Moreover, the tumour suppressor locus cyclin-dependent kinase inhibitor $2 A / B$ can affect pigmentation phenotypes in chicken [15]. Thus, it is reasonable for us to speculate that MCAM may play an important role in the determination of tail feather color. Future validation of this postulate of the MCAM gene function is warranted in chicken.

Besides the promising candidate gene MCAM, other candidate genes located in this $\sim 0.29 \mathrm{Mb}$ region have various functions (Table 2). For example, C1QTNF5, USP2 and NECTIN1 have been reported to be associated with diseases [29, 31, 33 ]. CBL can promote B cell receptor endocytosis and attenuate ligand-induced signaling [ 24 ]. RNF26 has been found to be associated with lysosomal positioning and movement [27]. THY1 correlated with myofibroblast apoptosis [32].

In this study, we also performed a comparative transcriptomic analysis of white-tailed ( 3 males and 3 females) versus black-tailed ( 3 males and 3 females) DW chickens (6-week old), but could not find genes differentially expressed in the two pigmentation phenotypes (data not shown). Our tail feather follicle transcriptome results suggested that the tail feather pigmentation may occur before the age of six weeks in DW chicken. 
Currently, the mechanism underlying the tail feather color is almost unknown. However, the GWAS results of this study may provide a clue for researchers to identify the relationship between these candidate genes and tail feather color. To investigate the genetic basis underlying the tail feather color of chicken, further research is necessary.

\section{Conclusions}

Our study showed that the white/black tail feather trait is autosome-linked in DW chickens. In addition, the GWAS revealed seven significant SNPs spanning a $\sim 0.29 \mathrm{Mb}$ region on GGA24 associated with the tail feather color in DW chickens, corresponding to 14 genes. Notably, among these 14 genes, MCAM may play critical roles in the formation of white/black tail feather color. Overall, the candidate genes detected herein can help elucidate the genomic architecture underlying the response to white/black tail feather and provide novel insights into the mechanisms underlying feather color development in DW chickens and other breeds.

\section{Abbreviations}

GWAS: Genome-wide association study; SNP: Single-nucleotide polymorphism; MDS: MultiDimensional scaling analysis; DQC: dish quality control; DL: Dwarf Layer; RIR: Rhode Island Red; DW: Dwarf line; GGA: Gallus gallus chromosome; MAF: Minor allele frequency;

\section{Declarations}

\section{Ethics approval and consent to participate}

All procedures and protocols involving animals were conducted in accordance with the Guidelines for the Care and Use of Experimental Animals established by the Ministry of Agriculture of China (Beijing, China). All animal work was approved by the Animal Welfare Committee of China Agricultural University (Beijing, China).

\section{Consent for publication}

Not applicable.

\section{Availability of data and material}

The data of this study have been uploaded on the NCBI database with the BioProject ID: GSE130568.

\section{Competing interests}

The authors declare that they have no competing interests.

\section{Funding}

This work was supported by funding from the National Nature Science Foundation of China [31672409] (cross experiment and DW genotyping), National Scientific Supporting Projects of China [2015BAD03B03] (RIR genotyping) and Beijing Innovation Team of the Modern Agro-industry Technology Research System [BAIC04-2018] (cross experiment).

\section{Authors' contributions}

LJQ, ZN and KW conceived and designed the experiments. CN and LQ performed the experiments. CN analyzed the data and wrote the paper. ZJ and LJQ revised the manuscript. All authors read and approved the final manuscript.

\section{References}


1. Griggio M, Valera F, Casas-Crivillé A, Hoi H, Barbosa A: White tail markings are an indicator of quality and affect mate preference in rock sparrows. Behavioral Ecology \& Sociobiology 2011, 65(4):655-664.

2. Kose M, Møller AP: Sexual selection, feather breakage and parasites: the importance of white spots in the tail of the barn swallow (Hirundo rustica). Behavioral Ecology and Sociobiology 1999, 45(6):430-436.

3. Weiss IM, Kirchner HO: The peacock's train (Pavo cristatus and Pavo cristatus mut. alba) I. structure, mechanics, and chemistry of the tail feather coverts. J Exp Zool A Ecol Genet Physiol 2010, 313A(10):690-703.

4. Cooke TF, Fischer CR, Wu P, Jiang TX, Xie KT, Kuo J, Doctorov E, Zehnder A, Khosla C, Chuong CM et al: Genetic Mapping and Biochemical Basis of Yellow Feather Pigmentation in Budgerigars. Cell 2017, 171(2):427-439 e421.

5. Delmore Kira E, Toews David PL, Germain Ryan R, Owens Gregory L, Irwin Darren E: The Genetics of Seasonal Migration and Plumage Color. Current Biology 2016, 26(16):2167-2173.

6. Kerje S, Sharma P, Gunnarsson U, Kim H, Bagchi S, Fredriksson R, Schutz K, Jensen P, von Heijne G, Okimoto R et al: The Dominant white, Dun and Smoky color variants in chicken are associated with insertion/deletion polymorphisms in the PMEL17 gene. Genetics 2004, 168(3):1507-1518.

7. Vaez M, Follett SA, Bed'hom B, Gourichon D, Tixier-Boichard M, Burke T: A single point-mutation within the melanophilin gene causes the lavender plumage colour dilution phenotype in the chicken. BMC genetics 2008, 9:7.

8. Chang CM, Coville JL, Coquerelle G, Gourichon D, Oulmouden A, Tixier-Boichard M: Complete association between a retroviral insertion in the tyrosinase gene and the recessive white mutation in chickens. BMC Genomics 2006, 7:19.

9. Dorshorst B, Okimoto R, Ashwell C: Genomic Regions Associated with Dermal Hyperpigmentation, Polydactyly and Other Morphological Traits in the Silkie Chicken. Journal of Heredity 2010, 101(3):339-350.

10. Gunnarsson U, Hellstrom AR, Tixier-Boichard M, Minvielle F, Bed'hom B, Ito S, Jensen P, Rattink A, Vereijken A, Andersson L: Mutations in SLC45A2 cause plumage color variation in chicken and Japanese quail. Genetics 2007, 175(2):867-877.

11. Kerje S, Lind J, Schutz K, Jensen P, Andersson L: Melanocortin 1-receptor (MC1R) mutations are associated with plumage colour in chicken. Anim Genet 2003, 34(4):241-248.

12. Charoensook R, Kewsri A, Incharoen T, Numthuam S, Soipeth U, Chirarat N, Rattanapradit P, Yaemkong S, Laorodphan N: Genetic diversity of gene MC1R in native chicken, black bone chicken, White Leghorn and Rhode Island Red. 2017.

13. Kerje S, Lind J, Schütz K, Jensen P, Andersson L: Melanocortin 1-receptor (MC1R) mutations are associated with plumage colour in chicken. Animal Genetics 2015, 34(4):241-248.

14. Dávila SG, Gil MG, Resinotalaván P, Campo JL, Rodríguez JA, Doblado BP, Lacosta JHC, Alibés MB, Martínez AA, Mata DV: Association between polymorphisms in the melanocortin 1 receptor gene (MC1R) and E locus plumage color phenotype in chickens. In: Xvi Jornadas Sobre Producción Animal, 19 Y 20 De Mayo De 2015, Zaragoza, España Tomo / \& II: $2015 ; 2015$.

15. Hellstrom AR, Sundstrom E, Gunnarsson U, Bed'Hom B, Tixier-Boichard M, Honaker CF, Sahlqvist AS, Jensen P, Kampe O, Siegel PB et al: Sex-linked barring in chickens is controlled by the CDKN2A /B tumour suppressor locus. Pigment cell \& melanoma research 2010, 23(4):521-530.

16. Green MR, Sambrook J: Isolation of High-Molecular-Weight DNA Using Organic Solvents. Cold Spring Harb Protoc 2017.

17. Kranis A, Gheyas AA, Boschiero C, Turner F, Le Y, Smith S, Talbot R, Pirani A, Brew F, Kaiser P: Development of a high density 600K SNP genotyping array for chicken. BMC Genomics 2013, 14(1):59-59.

18. Purcell S, Neale B, Todd-Brown K, Thomas L, Ferreira MAR, Bender D, Maller J, Sklar P, de Bakker PIW, Daly MJ et al: PLINK: A tool set for whole-genome association and population-based linkage analyses. American Journal of Human Genetics 2007, 81(3):559-575.

19. Price AL, Zaitlen NA, David R, Nick P: New approaches to population stratification in genome-wide association studies. Nat Rev Genet 2010, 11(7):459-463. 
20. Zhou X, Stephens M: Genome-wide efficient mixed-model analysis for association studies. Nat Genet 2012, 44(7):821-824.

21. Johnson RC, Nelson GW, Troyer JL, Lautenberger JA, Kessing BD, Winkler CA, O'Brien SJ: Accounting for multiple comparisons in a genome-wide association study (GWAS). BMC Genomics 2010, 11.

22. Gu X, Feng C, Ma L, Song C, Wang Y, Da Y, Li H, Chen K, Ye S, Ge C et al: Genome-Wide Association Study of Body Weight in Chicken F2 Resource Population. PloS one 2011, 6(7).

23. Nicodemus KK, Liu W, Chase GA, Tsai YY, Fallin MD: Comparison of type I error for multiple test corrections in large single-nucleotide polymorphism studies using principal components versus haplotype blocking algorithms. BMC genetics 2005, 6 Suppl 1:S78.

24. Jacob M, Todd L, Sampson MF, Pure E: Dual role of Cbl links critical events in BCR endocytosis. International immunology 2008, 20(4):485-497.

25. Gao Q, Zhang J, Wang X, Liu Y, He R, Liu X, Wang F, Feng J, Yang D, Wang Z et al: The signalling receptor MCAM coordinates apicalbasal polarity and planar cell polarity during morphogenesis. Nature communications 2017, 8:15279.

26. Guezguez B, Vigneron P, Lamerant N, Kieda C, Jaffredo T, Dunon D: Dual role of melanoma cell adhesion molecule (MCAM)/CD146 in lymphocyte endothelium interaction: MCAM/CD146 promotes rolling via microvilli induction in lymphocyte and is an endothelial adhesion receptor. Journal of immunology (Baltimore, Md : 1950) 2007, 179(10):6673-6685.

27. Cabukusta B, Neefjes J: Mechanisms of lysosomal positioning and movement. Traffic 2018, 19(10):761-769.

28. Dinculescu A, Dyka FM, Min SH, Stupay RM, Hooper MJ, Smith WC, Hauswirth WW: Co-Expression of Wild-Type and Mutant S163R C1QTNF5 in Retinal Pigment Epithelium. Advances in experimental medicine and biology 2018, 1074:61-66.

29. Stanton CM, Borooah S, Drake C, Marsh JA, Campbell S, Lennon A, Soares DC, Vallabh NA, Sahni J, Cideciyan AV et al: Novel pathogenic mutations in C1QTNF5 support a dominant negative disease mechanism in late-onset retinal degeneration. Scientific reports 2017, 7(1):12147.

30. Schwartze JT, Landgraf K, Spielau U, Rockstroh D, Loffler D, Kratzsch J, Kiess W, Korner A: Adipocyte C1QTNF5 expression is BMIdependently related to early adipose tissue dysfunction and systemic CTRP5 serum levels in obese children. International journal of obesity (2005) 2017, 41(6):955-963.

31. Zhu HQ, Gao FH: The Molecular Mechanisms of Regulation on USP2's Alternative Splicing and the Significance of Its Products. International journal of biological sciences 2017, 13(12):1489-1496.

32. Liu X, Wong SS, Taype CA, Kim J, Shentu TP, Espinoza CR, Finley JC, Bradley JE, Head BP, Patel HH et al: Thy-1 interaction with Fas in lipid rafts regulates fibroblast apoptosis and lung injury resolution. Laboratory investigation; a journal of technical methods and pathology 2017, 97(3):256-267.

33. Takahashi Y, Yamamichi N, Inada KI, Shiogama K, Sakurai K, Takeuchi C, Mizutani Y, Tsutsumi Y, Koike K: Nectin1 expression is frequently decreased in gastric cancers. Pathology international 2018, 68(10):557-562.

34. Hayashi R, Abe R, Shimomura Y: Expression studies of nectin-1 in human hair follicles and identification of a p63-responsive element in the NECTIN1 promoter. Journal of dermatological science 2016, 84(2):221-224.

35. Yu M, Yue Z, Wu P, Wu DY, Mayer JA, Medina M, Widelitz RB, Jiang TX, Chuong CM: The biology of feather follicles. The International journal of developmental biology 2004, 48(2-3):181-191.

36. Kim M, Han JH, Kim JH, Park TJ, Kang HY: Secreted Frizzled-Related Protein 2 (sFRP2) Functions as a Melanogenic Stimulator; the Role of sFRP2 in UV-Induced Hyperpigmentary Disorders. Tetrahedron Letters 2016, 136(1):236-244.

37. Muriel C-A, Catherine P, Yvon G, Vincent C, Alain T: In vivo and in vitro evidence of dermal fibroblasts influence on human epidermal pigmentation. Pigment cell \& melanoma research 2010, 19(5):434-442.

38. Mangahas CR, dela Cruz GV, Schneider RJ, Jamal S: Endothelin-1 upregulates MCAM in melanocytes. The Journal of investigative dermatology 2004, 123(6):1135-1139.

Page $7 / 12$ 
39. Dorshorst B, Molin AM, Rubin CJ, Johansson AM, Stromstedt L, Pham MH, Chen CF, Hallbook F, Ashwell C, Andersson L: A complex genomic rearrangement involving the endothelin 3 locus causes dermal hyperpigmentation in the chicken. PLoS genetics 2011, 7(12):e1002412.

40. Chen GH, Wang KH, Wang JY, Ding C, Yang N: Poultry Genetic Resources in China. Shanghai Scientific and Technological Press, Shanghai, China 2004.

\section{Tables}

Table 1. Progeny phenotypes of eight crosses in the Dwarf chicken population.

\begin{tabular}{|c|c|c|c|c|c|c|c|c|c|}
\hline Cross & Patents & & $\begin{array}{l}\text { Black- } \\
\text { tailed } \\
\text { offspring }\end{array}$ & & $\begin{array}{l}\text { White- } \\
\text { tailed } \\
\text { offspring }\end{array}$ & & $\begin{array}{l}\text { Mottled } \\
\text { offspring }\end{array}$ & & $\begin{array}{l}\text { Gray-tailed } \\
\text { offspring }\end{array}$ \\
\hline & Male & Female & Male & Female & Male & Female & Male & Female & \\
\hline 1 & $\mathrm{~B}^{1}$ & B & 66 & 58 & $1^{3}$ & 0 & 0 & 0 & / \\
\hline 2 & B & $W^{2}$ & 26 & 36 & 49 & 39 & 0 & 7 & / \\
\hline 3 & W & $B$ & 26 & 27 & 14 & 27 & 0 & 6 & I \\
\hline 4 & W & W & 6 & 8 & 53 & 62 & 0 & 20 & / \\
\hline 5 & $B$ & $B$ & 146 & & $1^{3}$ & & / & & 0 \\
\hline 6 & $B$ & W & 68 & & 74 & & / & & 7 \\
\hline 7 & W & $B$ & 33 & & 46 & & / & & 2 \\
\hline 8 & W & W & 16 & & 104 & & / & & 4 \\
\hline
\end{tabular}

1Black tail feather; 2White tail feather; 30utlier, assuming that white tail feather color in the DW chicken is an autosome-linked dominant trait.

\section{Candidate genes on chromosome 24 detected by the GWAS}

Table 2. SNPs significantly associated with the tail feather color in the GWAS. 


\begin{tabular}{|c|c|c|c|c|c|c|c|c|c|}
\hline SNP & GGA1 & $\begin{array}{l}\text { Position2 } \\
\text { (bp) }\end{array}$ & $\begin{array}{l}\text { Minor/ } \\
\text { major }\end{array}$ & $\begin{array}{l}P \\
\text { value }\end{array}$ & MAF3 & & $\begin{array}{l}\text { Candidate genes } \\
\text { (location (kb)4) }\end{array}$ & Full name & Functions \\
\hline & & & & & DW & RIR & & & \\
\hline rs314910357 & 24 & $4,235,437$ & $\mathrm{~T} / \mathrm{C}$ & $\begin{array}{l}1.12 \mathrm{e}- \\
07\end{array}$ & 0.14 & 0.00 & $C B L$ (Intron) & $\begin{array}{l}\text { Cbl proto- } \\
\text { oncogene }\end{array}$ & $\begin{array}{l}\text { B cell receptors } \\
\text { endocytosis } \\
\text { and ligand- } \\
\text { induced } \\
\text { signaling [24]. }\end{array}$ \\
\hline rs313984397 & 24 & $4,258,648$ & $\mathrm{C} / \mathrm{T}$ & $\begin{array}{l}1.54 \mathrm{e}- \\
07\end{array}$ & 0.16 & 0.00 & CCDC153 (Intron) & $\begin{array}{l}\text { Coiled-coil } \\
\text { domain } \\
\text { containing } \\
153\end{array}$ & NA \\
\hline \multirow[t]{2}{*}{ rs317369751 } & 24 & $4,209,809$ & $\mathrm{~T} / \mathrm{C}$ & $\begin{array}{l}1.64 \mathrm{e}- \\
07\end{array}$ & 0.11 & 0.00 & MCAM (Intron) & $\begin{array}{l}\text { Melanoma } \\
\text { cell } \\
\text { adhesion } \\
\text { molecule }\end{array}$ & $\begin{array}{l}\text { Coordinate } \\
\text { morphogenesis } \\
\text { process [25] } \\
\text { and endothelial } \\
\text { adhesion [26]. }\end{array}$ \\
\hline & & & & & & & RNF26 (D7.14) & $\begin{array}{l}\text { Ring finger } \\
\text { protein } 26\end{array}$ & $\begin{array}{l}\text { Lysosomal } \\
\text { positioning } \\
\text { and movement } \\
\text { [27]. }\end{array}$ \\
\hline \multirow[t]{6}{*}{ rs313530951 } & 24 & $4,190,968$ & $A / G$ & $\begin{array}{l}1.65 \mathrm{e}- \\
07\end{array}$ & 0.11 & 0.00 & $\begin{array}{l}\text { ENSGALG00000032979 } \\
\text { (Intron) }\end{array}$ & NA & NA \\
\hline & & & & & & & C1QTNF5 (U2.25) & $\begin{array}{l}\mathrm{C} 1 \mathrm{q} \text { and } \\
\mathrm{TNF} \\
\text { related } 5\end{array}$ & $\begin{array}{l}\text { Disease related } \\
{[28-30] .}\end{array}$ \\
\hline & & & & & & & USP2 (D3.82) & $\begin{array}{l}\text { Ubiquitin } \\
\text { specific } \\
\text { peptidase } \\
2\end{array}$ & $\begin{array}{l}\text { Cell growth or } \\
\text { death and } \\
\text { disease related } \\
\text { [31]. }\end{array}$ \\
\hline & & & & & & & $\begin{array}{l}\text { ENSGALG00000039907 } \\
\text { (U8.51) }\end{array}$ & NA & \\
\hline & & & & & & & THY1 (D17.10) & $\begin{array}{l}\text { Thy-1 cell } \\
\text { surface } \\
\text { antigen }\end{array}$ & $\begin{array}{l}\text { Myofibroblast } \\
\text { apoptosis [32]. }\end{array}$ \\
\hline & & & & & & & gga-mir-1466 (D17.03) & $\begin{array}{l}\text { gga-mir- } \\
1466\end{array}$ & NA \\
\hline rs316093292 & 24 & $3,966,635$ & $\mathrm{~T} / \mathrm{C}$ & $\begin{array}{l}3.00 \mathrm{e}- \\
07\end{array}$ & 0.06 & 0.00 & NECTIN1 (U65.13) & $\begin{array}{l}\text { Nectin cell } \\
\text { adhesion } \\
\text { molecule } \\
1\end{array}$ & $\begin{array}{l}\text { Disease related } \\
\text { [33], hair } \\
\text { follicle } \\
\text { morphogenesis } \\
\text { [34]. }\end{array}$ \\
\hline \multirow[t]{2}{*}{ rs313273705 } & 24 & $4,137,245$ & $\mathrm{G} / \mathrm{A}$ & $\begin{array}{l}3.46 \mathrm{e}- \\
07\end{array}$ & 0.08 & 0.00 & $\begin{array}{l}\text { ENSGALG00000006746 } \\
\text { (D47.62) }\end{array}$ & NA & NA \\
\hline & & & & & & & $\begin{array}{l}\text { ENSGALG00000037367 } \\
\text { (D37.50) }\end{array}$ & NA & NA \\
\hline rs317350539 & 24 & $4,018,982$ & $\mathrm{G} / \mathrm{A}$ & $\begin{array}{l}3.62 \mathrm{e}- \\
07\end{array}$ & 0.13 & 0.00 & $\begin{array}{l}\text { ENSGALG00000046117 } \\
\text { (U13.32) }\end{array}$ & NA & NA \\
\hline
\end{tabular}

1Chicken chromosome; 2Position of SNPs according to the reference Gallus_gallus-5.0 primary assembly. 3 Minor allele frequency; $4 \mathrm{U}$ and $D$ indicate that the SNP is upstream and downstream of a gene, respectively.

\section{Figures}



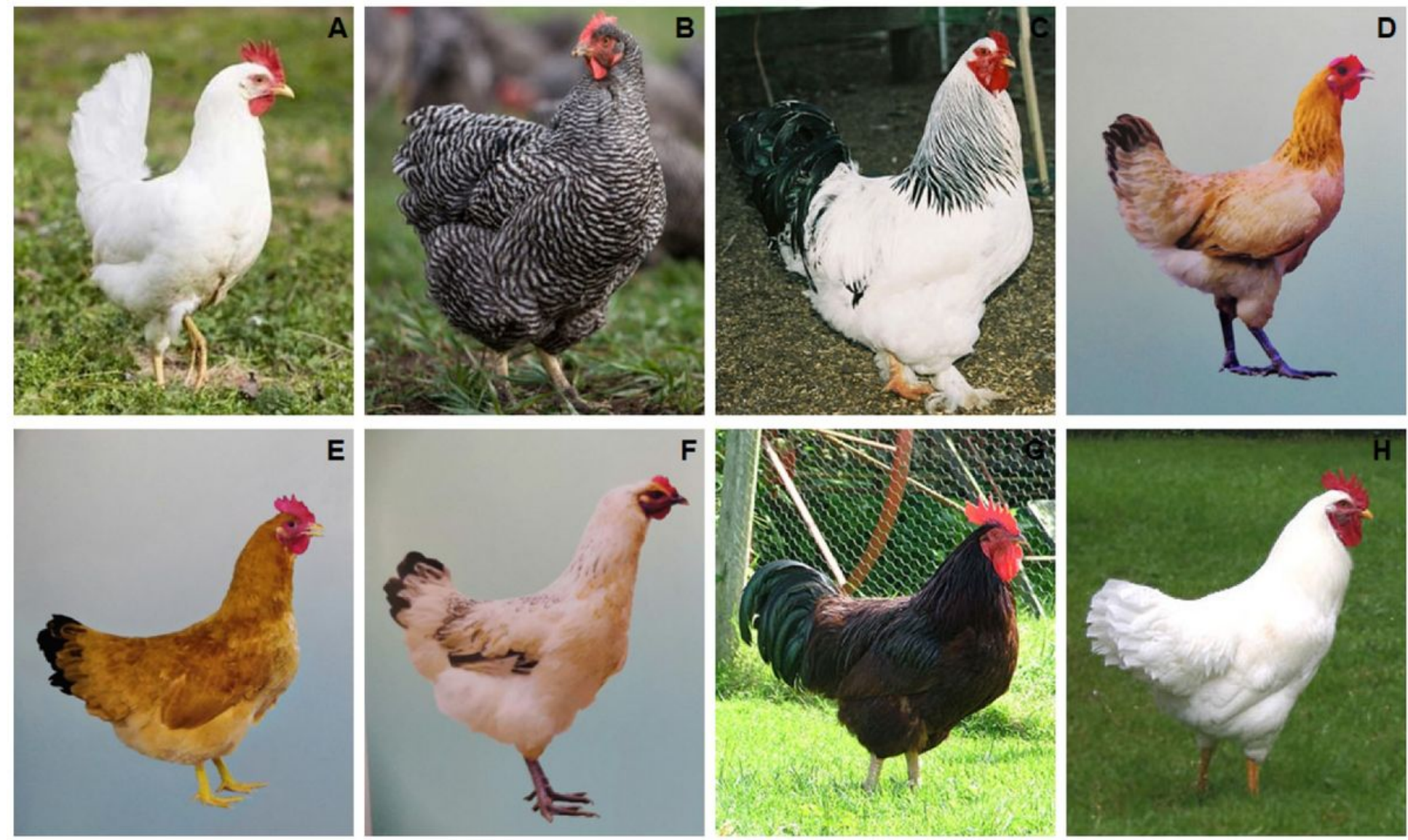

\section{Figure 1}

Chicken Phenotype. (A) White Leghorn chicken; (B) Plymouth Rock chicken; (C) Brahma chicken; (D) Shuanglian chicken; (E) Xiaoshan chicken; (F) Jingyang chicken; (G) Rhode Island Red; (H) Rhode Island White. Image Source: efowl.com (A), chickeneggspert.com (B, C, G, and $H)$, Chen et al., (D, E, and F) [40]. 


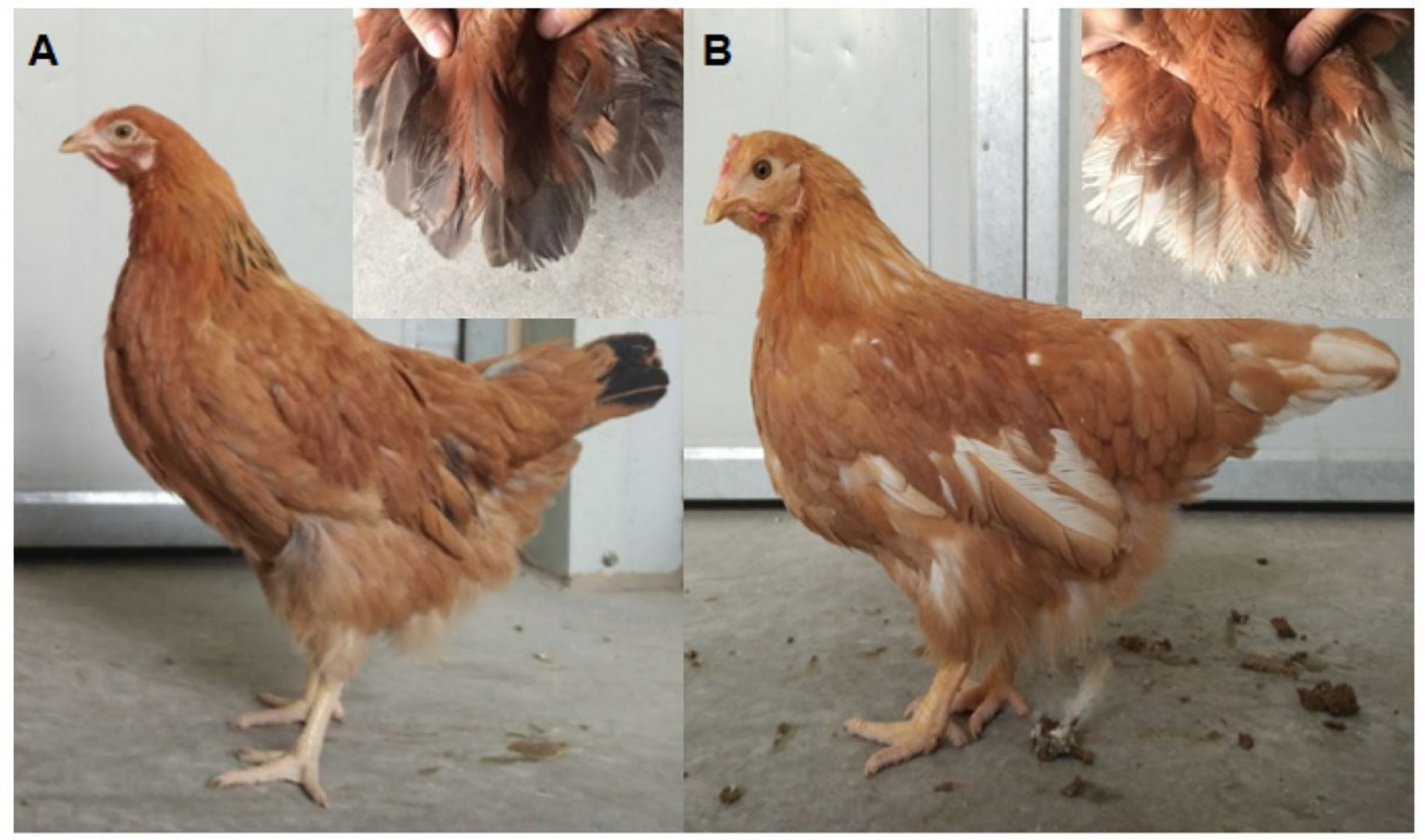

\section{Figure 2}

Dwarf hens with the white or black tail feather color. (A) Black tail; (B) White tail.

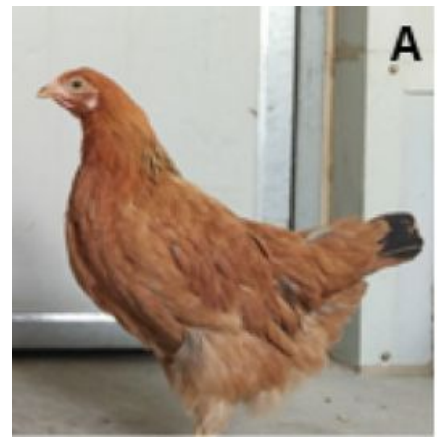

우 Black tail

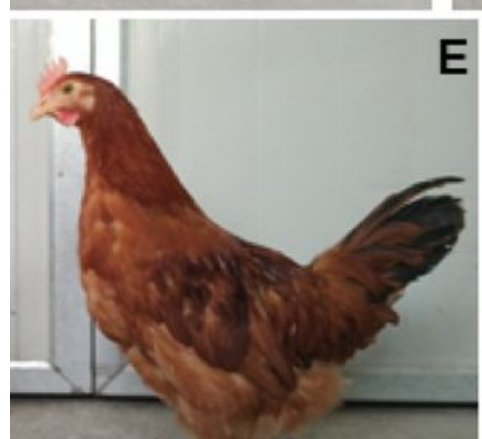

Black tail
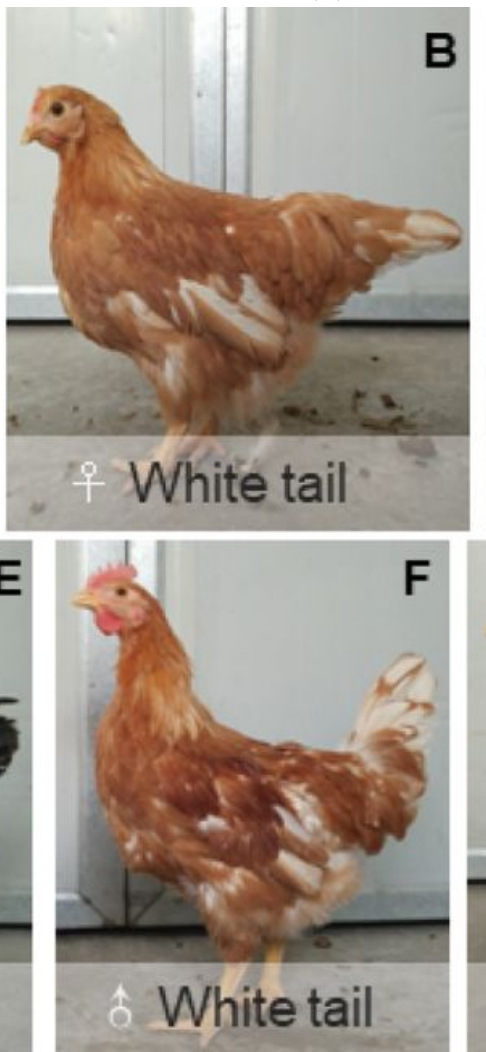

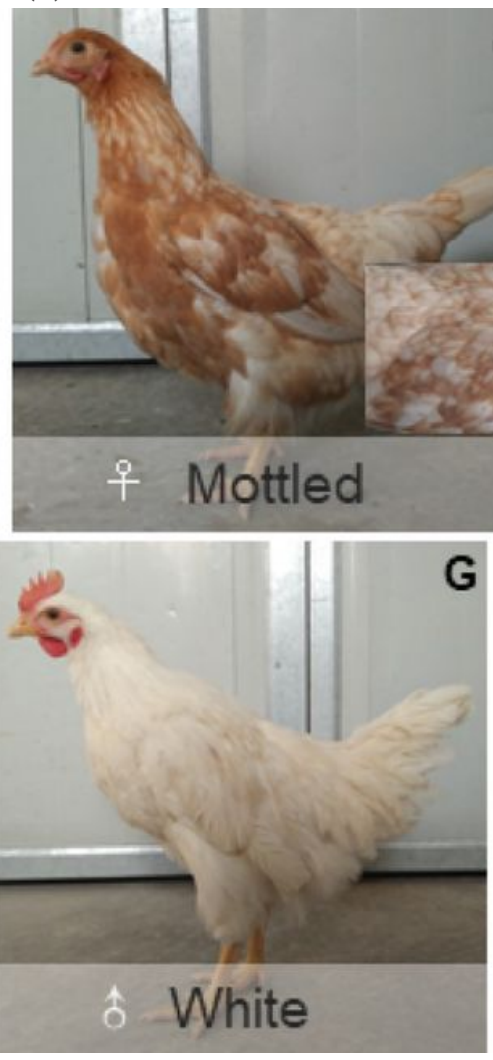

$c$
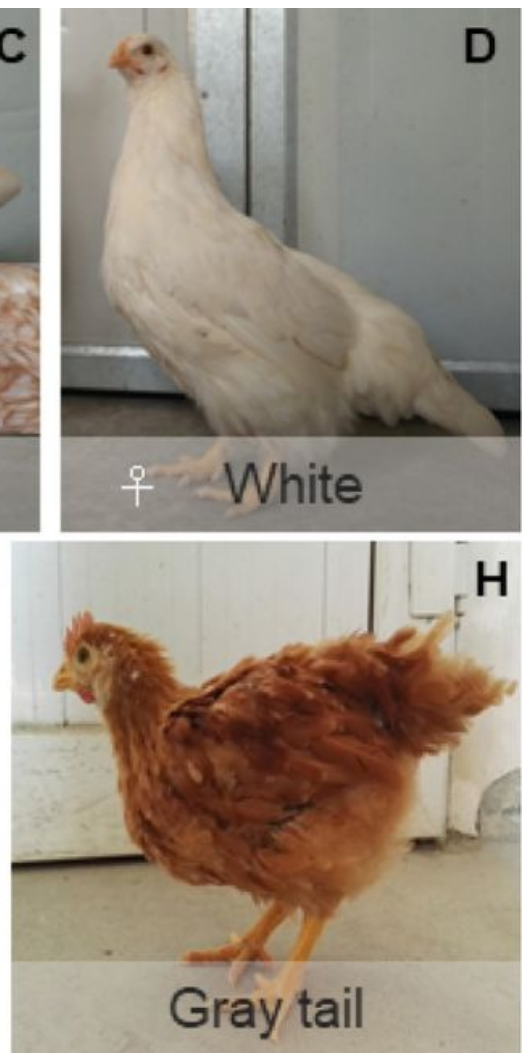

Figure 3 
Principal feather color subtypes in Dwarf offspring chickens. A-D show the different feather color phenotypes of Dwarf hens, E-G show the different feather color phenotypes of Dwarf cocks. $F$ shows the gray tail feather in some offspring.

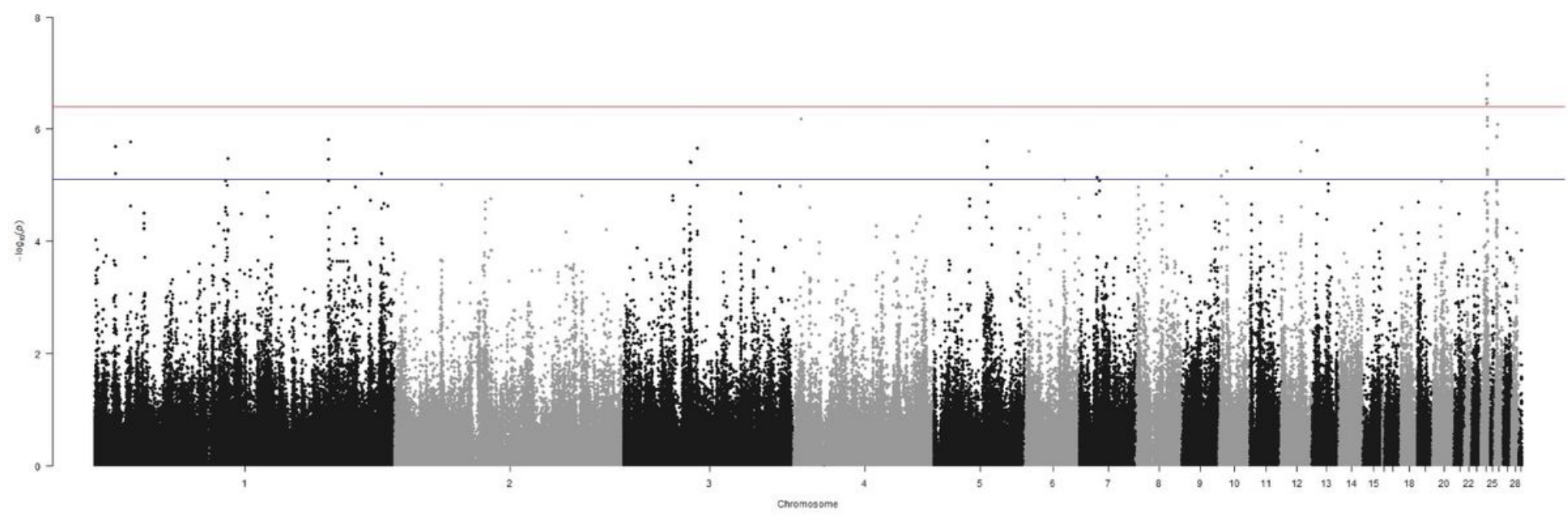

Figure 4

Manhattan plot showing the association of all SNPs with the tail feather color (white/black) trait of Dwarf and Rhode Island Red chickens. SNPs were plotted on the $x$-axis according to their position on each chromosome against their association with these traits on the $y$-axis (shown as -log10 P-value). The red line and blue line indicate the genome-wide and suggestive significant association with Pvalues of $3.97 \times 10-7(0.05 / 125,985)$ and $7.94 \times 10-6(1 / 125,985)$, respectively. 